\title{
Distribution and Feeding of the Sea Cucumber Isostichopus badionotus in Relation to Shelter and Sediment Criteria of the Bermuda Platform*
}

\author{
N. A. Sloan** and B. von Bodungen \\ Bermuda Biological Station, St. George's West 1-15, Bermuda
}

\begin{abstract}
The distribution (habitat preference) of the holothurian Isostichopus badionotus (Selenka) on the Bermuda platform is related primarily to shelter from wave action. Within sheltered habitats I. badionotus occupies stable rocky, sandy or muddy substrates with epibenthic biota. $I$. badionotus of similar size are unselective feeders with regard to particle size of muddy or sandy sediments. I badionotus can ingest its own feces, which may provide a potentially enriched food resource that is unlikely to persist in areas of turbulent water conditions. The first summary of knowledge on stichopodid feeding is provided. It is suggested that the absence of deposit-feeding holothurians co-occuring with $I$. badionotus may allow the latter to occupy so many different sheltered habitats, because in more tropical reef flat habitats coexisting holothurian species have better defined habitat and sediment-food requirements.
\end{abstract}

\section{INTRODUCTION}

Holothurians (Echinodermata: Holothuroidea) can occur in great numbers on sheltered shallow-water sediments in the tropics. In these habitats they are important reworkers of sediments (Bakus, 1973; Webb et al., 1977). From sediments they assimilate microorganisms associated with both organic and inorganic material (Yingst, 1976). Despite their ecological importance, holothurians have received little attention from ecologists; hence our understanding of their feeding biology and of the ecological effects of deposit feeding by tropical holothurians (Bakus, 1973) is incomplete.

We are reporting here on distribution (habitat preferences) and gut contents of Isostichopus badionotus (Selenka), still often referred to as Stichopus moebii Semper, on the Bermuda platform. I. badionotus is a common, large (up to $30 \mathrm{~cm}$ long), epibenthic species widely distributed on shallow muddy, sandy and sea grass beds from Central America to West Africa and from Ascension to Bermuda (Pawson, 1976, 1978). The abundance of $I$. badionotus around Bermuda was studied in relation to exposure to water turbulence and

\footnotetext{
- Contribution No. 818 of the Bermuda Biological Station and Sonderforschungsbereich 95, Publication No. 256.

- Present address: 3249 W. 49th Ave., Vancouver, B.C., Canada V6N 3TF.
}

sediment grain sizes. Within a sheltered habitat the abundance, biomass and sediment-feeding of $I$. badionotus as related to sediment porosity, grain sizes, total organic material and total phosphorus is discussed. Grain sizes of gut contents are compared with those of ambient sediments to estimate feeding selectivity.

The holothurian fauna in semi-tropical Bermuda, like its marine fauna generally, is depauperate (W. E. Sterrer, personal communication). Isostichopus badionotus is the only common, conspicuous epibenthic holothurian species wheras in other, albeit warmer, shallow-water habitats, complexes of large epibenthic (Yamanouti, 1939; Yanamouchi, 1956; Trefz, 1958 in Bakus, 1973; Rowe and Doty, 1977; Roberts, 1979; Lawrence, 1980) or smaller cryptic (Sloan, 1979) holothurian species usually co-occur. Since the co-occuring species may use a combination of reef flat zonation, substrate type, feeding and behavioural differences to partition resources, it is of interest to analyze some of these factors for the solitary $I$. badionotus from Bermuda.

\section{MATERIALS AND METHODS}

Areas were sampled around the Bermuda platform as well as in sheltered inshore waters like Harrington Sound (Fig. 1). Divers collected surface sediments and 


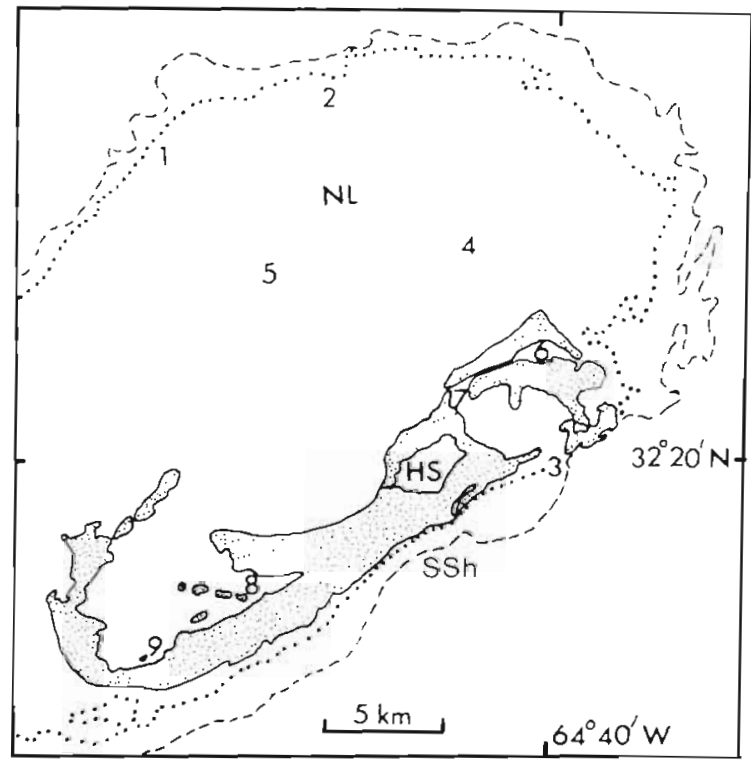

Fig. 1. Bermuda Islands and their surrounding platform (after Morris et al., 1977). Dotted line: outer reef edge; dashed line: $20 \mathrm{~m}$ isobath. Numbers correspond to the 9 sampling sites listed in Table 1. NL: North Lagoon; HS: Harrington Sound; SSh: South Shore

made holothurian counts on three $20 \mathrm{~m}$ long $\times 2 \mathrm{~m}$ wide transects at each site, except Harrington Sound. Since Isostichopus badionotus is a surface sediment feeder, samples within the first $2.5 \mathrm{~cm}$ only were taken except in Harrington Sound. To determine grain size classes, the sediments were wet-sieved to remove the majority of fine particles $(<140 \mu \mathrm{m})$; the remaining coarser material was rinsed with fresh water, dried at $70^{\circ} \mathrm{C}$ and then sieved.

Within the different zones in Harrington Sound (Fig. 2), a total of 38 stations were sampled (Fig. 3). At each station the depth was recorded, a $23.74 \mathrm{~cm}^{2}$ core of $5 \mathrm{~cm}$ depth was taken and a $20 \mathrm{~m}$ long $\times 1 \mathrm{~m}$ wide transect sampled. Each core was divided into $0-2.5 \mathrm{~cm}$ and $2.5-5.0 \mathrm{~cm}$ strata; the sediments were examined for porosity and total organic material. Porosity was calculated according to the method of Bemer (1971, p. 92). Total organic material (TOM) of sediments was estimated by the loss of weight on ignition at $500^{\circ} \mathrm{C}$ of a dried sample.

The zones in Harrington Sound are the 'Shallow Sandy Zone' which includes a 'Cladophora Zone' formed by the recent invasion of mats of Cladophora prolifera (Roth), the 'Oculina Zone' characterized by the sediment-dwelling coral Oculina valenciennesi Edwards and Haime and the deep North and South Muddy Zones' which are identical to Neumann's (1965) 'Subthermocline Zone'.

A shallow, isolated ridge, indicated in Figure 3, was investigated in order to compare holothurian gut con-

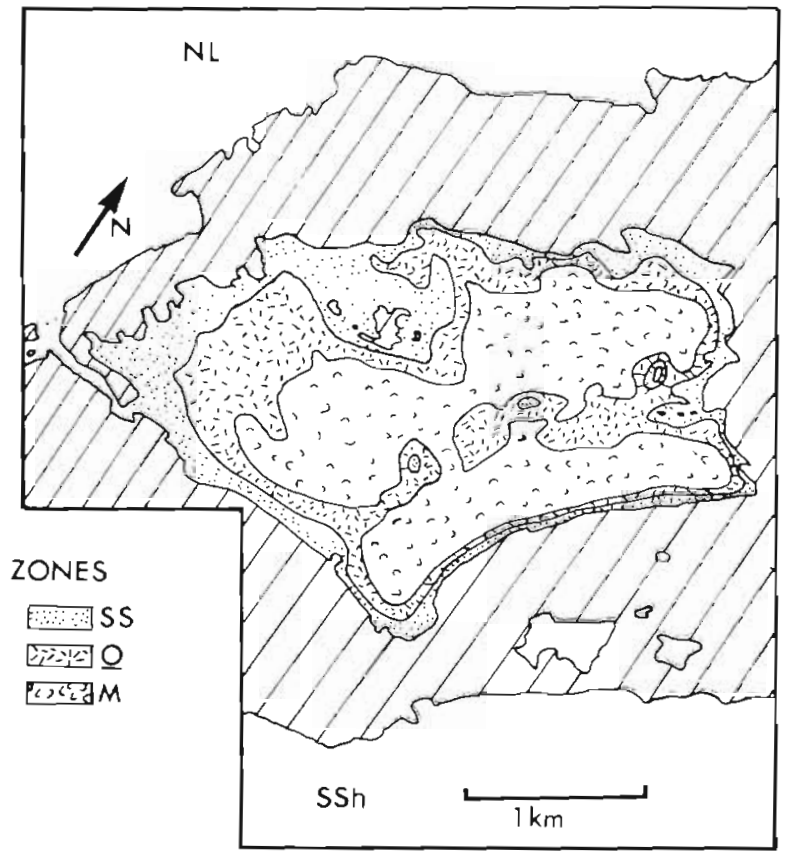

Fig. 2. Ecological zones of Harrington Sound. (After Neumann, 1965.) SS: Shallow Sandy Zone; O: Oculina; M: Muddy; NL; North Lagoon; SSh: South Shore

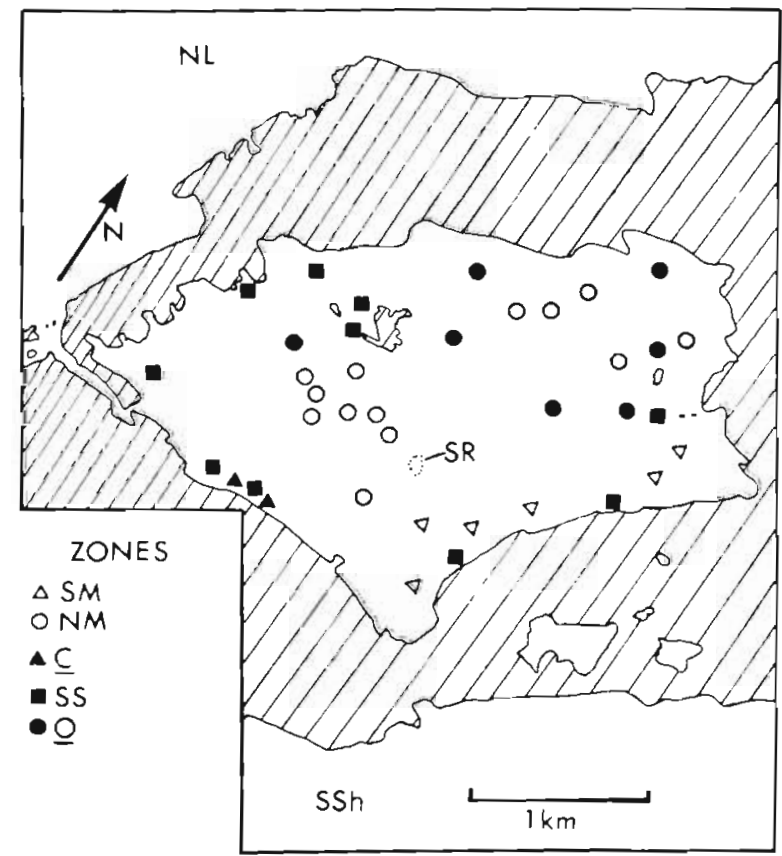

Fig. 3. Sampling site distribution in Harrington Sound. (After Barnes and von Bodungen, 1978.) SM: South Muddy Zone; NM: North Muddy; C: Cladorphora; SS: Shallow Sandy; O: Oculina. SR: shallow, isolated ridge; NL: North Lagoon; SSh: South Shore

tents with ambient sediments from the Shallow Sandy and Oculina Zones. Entire guts were excised from holothurians and the contents, similarly to ambient 
sediments, examined for grain size classes as mentioned above. Since Isostichopus badionotus was observed ingesting fecal casts in this area, feces and ambient sediments in front of animals were examined for TOM and total phosphorus (TP) in order to compare their content in potential nutrients. TP was estimated after ignition at $500^{\circ} \mathrm{C}$ for $2 \mathrm{~h}$ of a preweighed sample, which was then boiled in $3 \% \mathrm{HCl}$ for $0.5 \mathrm{~h}$; the remaining liquid was filled up to $100 \mathrm{ml}$ with deionized water and the phosphates determined according to Strickland and Parsons (1972). Five $20 \mathrm{~m}$ long $\times 1 \mathrm{~m}$ wide transects were sampled in each Zone for an estimation of holothurian abundance, and 100 individuals from each Zone were measured in situ and undisturbed for body length estimation. A subsample of 20 of these were eviscerated to remove the sediment-filled gut, and the blotted body walls were weighed for an estimation of biomass. Five body walls were examined for TOM as a percentage of live weight.

\section{RESULTS}

\section{Habitat Preferences on the Bermuda Platform}

Table 1 lists holothurian abundance and sediment grain sizes from the sites around Bermuda. At the highenergy reef edges of North Lagon and South Shore
(Fig. 1, Sites 1-3), the sediment patches were rippled and devoid of epibiota. The sediments contain mostly coarse material, the fines being readily resuspended and deposited elsewhere. The patch reefs in North Lagoon (Sites 4 and 5) are more sheltered with more fine material in their surrounding sediments and established communities of epibenthos which were described in deatil by Garrett et al. (1971), Jordan (1973) and Scoffin and Garrett (1974). In the sheltered inshore areas holothurians occur on sandy sea-grass beds (Site 7), with their relatively rich fauna (Orth, 1971), but not on high-sedimentation areas with sparse epibenthos like the shipping channels of Hamilton and St. George's Harbours (Sites 6 and 8a). Dense stands of sea grass in Ferry Reach contain fewer individuals than mixed, patchy stands. Isostichopus badionotus is common on sandy or rock ledge substrates with well established epibenthos around the islands of Hamilton Harbour and Little Sound (Sites $8 b$ and 9). The rock ledge has a thin layer of relatively fine sediment.

\section{Distribution in Harrington Sound}

Table 2 contains data on holothurian abundance and various sediment criteria from stations within the different ecological Zones of Harrington Sound, a sheltered inshore area.

Isostichopus badionotus is restricted to the Shallow

Table 1. Holothurian abundance and sediment grain size classes from different sites on Bermuda platform (sediment depth: $0-2.5 \mathrm{~cm}$ )

\begin{tabular}{|c|c|c|c|c|c|c|c|c|}
\hline \multirow{2}{*}{ Sites ${ }^{*}$} & \multirow{2}{*}{$\begin{array}{l}\text { Water } \\
\text { depth } \\
(\mathrm{m})\end{array}$} & \multirow{2}{*}{$\begin{array}{l}\text { Holothurians } \\
120 \mathrm{~m}^{-2}\end{array}$} & \multicolumn{6}{|c|}{ Grain size $(\mu \mathrm{m})$ classes as dry weight $(\%)$} \\
\hline & & & $>2,000$ & $2,000-700$ & $700-515$ & $515-250$ & $250-140$ & $<140$ \\
\hline \multicolumn{9}{|l|}{ Offshore waters } \\
\hline (1) Reef edge of North Lagoon & 10 & 0 & 78.60 & 20.70 & 0.42 & 0.14 & 0.07 & 0.07 \\
\hline (2) Reef edge near North Rock & 6 & 0 & 70.25 & 22.45 & 4.10 & 3.20 & 0.00 & 0.00 \\
\hline (3) South Shore off Castle Harbour & 8 & 0 & 10.83 & 63.50 & 2.10 & 18.87 & 4.36 & 0.35 \\
\hline (4) Patch reef in North Lagoon & 11 & $14\left(0.12 \mathrm{~m}^{-2}\right)$ & 5.90 & 32.00 & 6.80 & 9.60 & 7.30 & 38.40 \\
\hline (5) Patch reef in North Lagoon & 10 & $27\left(0.22 \mathrm{~m}^{-2}\right)$ & 3.10 & 23.80 & 10.40 & 22.70 & 10.00 & 30.00 \\
\hline \multicolumn{9}{|l|}{ Inshore waters } \\
\hline (6) St. George's Harbour, shipping channel & 12 & 0 & 2.90 & 5.90 & 2.50 & 12.00 & 12.60 & 64.10 \\
\hline (7) Ferry Reach, sea grass beds (a) $\cdots$ & 2 & $2\left(0.92 \mathrm{~m}^{-2}\right)$ & 3.68 & 38.17 & 12.37 & 25.35 & 14.35 & 6.08 \\
\hline (b) $\cdots$ & 1.5 & $20\left(0.16 \mathrm{~m}^{-2}\right)$ & 9.20 & 23.40 & 11.83 & 37.33 & 11.08 & 7.60 \\
\hline \multicolumn{9}{|l|}{ (8) Hamilton Harbour } \\
\hline (a) shipping channel & 15 & 0 & 9.73 & 16.60 & 12.58 & 24.16 & 13.92 & 23.01 \\
\hline $\begin{array}{l}\text { (b) west side of Marshal Island } \\
\text { (9) Little Sound, Five Star Is. }\end{array}$ & 5 & $26\left(0.22 \mathrm{~m}^{-2}\right)$ & 24.04 & 28.23 & 9.35 & 22.71 & 11.24 & 4.43 \\
\hline (a) wide rock ledge & 2.5 & $\begin{array}{l}17 \cdots \\
\quad\left(0.42 \mathrm{~m}^{-2}\right)\end{array}$ & 6.40 & 18.68 & 7.88 & 20.20 & 13.79 & 32.05 \\
\hline (b) level bottom at ledge base & 6 & $92\left(0.76 \mathrm{~m}^{-2}\right)$ & 17.88 & 30.83 & 9.48 & 27.24 & 11.73 & 2.84 \\
\hline $\begin{array}{l}\quad \text { See Figure } 1 \text { for localities. } \\
\cdots \text { Dense stand of 'Manatee grass' Syrin } \\
\cdots \text { Patchy, mixed stand of } S \text {. filiforme and } \\
\cdots\end{array}$ & $\begin{array}{l}\text { ngodiun } \\
\text { id Thalc }\end{array}$ & $\begin{array}{l}\text { m filiforme Küt } \\
\text { lassia testudinu }\end{array}$ & $\begin{array}{l}\text { tzing. } \\
\text { um Koeni }\end{array}$ & ig \& Sims. & & & & \\
\hline
\end{tabular}




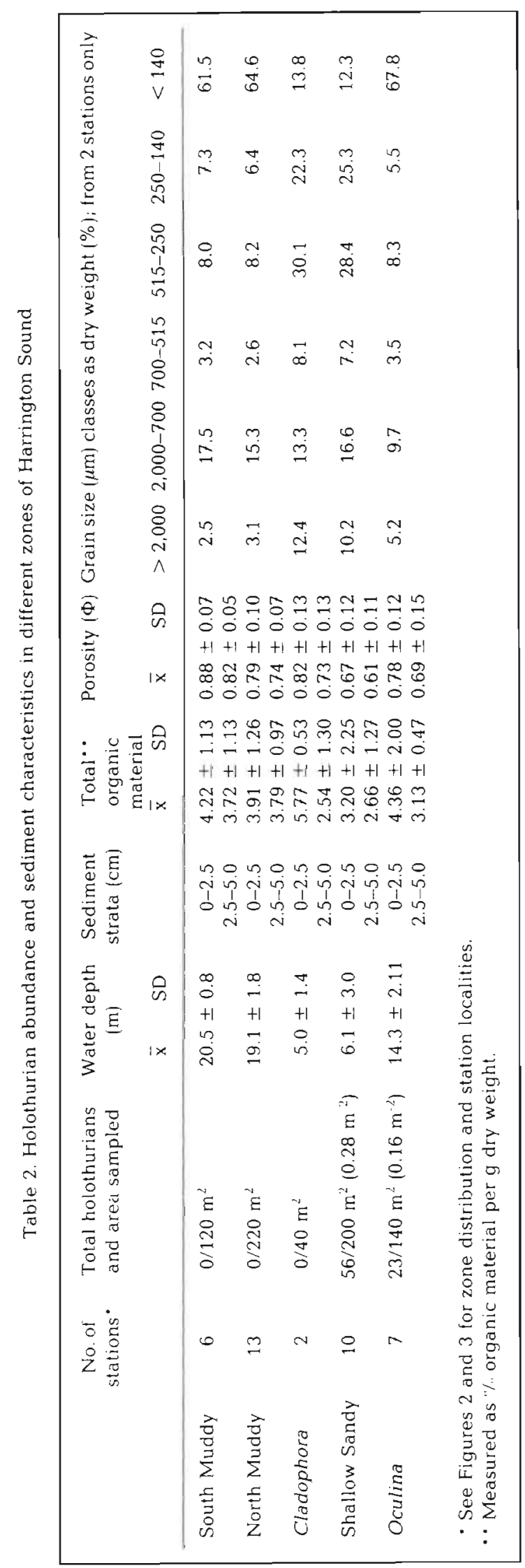

Sandy and Oculina Zones. The latter is made topographically more complex by the presence of Oculina heads and their associated biota. It also has much more fine and porous sediments on the patches between the heads, to which the holothurians are restricted. The organic material content of the Oculina Zone top sediment is greater, although fewer holothurians are present than in the Shallow Sandy Zone.

\section{Feeding, Population Density and Sediment Criteria in Harrington Sound}

Table 3 shows that holothurian numbers and biomasses are greater in the Shallow Sandy Zone. The length and weight structure of the populations from both Zones is similar. Holothurians from these 2 Zones are unselective in regard to the sediments they ingest (Table 4). Holothurian guts and ambient sediments contain similar relative amounts of the particle size classes examined. There is a slight tendency for the holothurians in the Oculina Zone to ingest the finest and coarsest particles available.

Among the many observations of actively feeding Isostichopus badionotus, individuals were twice observed ingesting fecal casts which, in both cases, were well consolidated. Casts remain intact for at least $2 \mathrm{~d}$. Preliminary results in Table 5 show that both total organic material and total phosphorus are greater in the holothurian feces from the Shallow Sandy and Oculina Zones than in the ambient sediments.

\section{DISCUSSION}

The distribution, i.e. habitat preference, of Isostichopus badionotus around Bermuda is related to shelter from turbulent areas, not to depth (Table 1). Shelter from wave action is the key factor influencing the distribution of most holothurians on tropical reef flats (Bakus, 1973). Within sheltered areas I. badionotus occurs on rocky, sandy and muddy substrates with an epibenthic community. Sheltered sandy areas around small inshore islands, patch reefs or associated with sea-grass beds are preferred habitats. If the epiflora is too dense (Caldophora mats or thick stands of sea grass) and thus prevents access to the sediments, holothurians are rare. Unstable muddy areas with little or no epibiota like the shipping channels in Hamilton or St. George's Harbours or the deeps of Harrington Sound have no holothurians. In these areas sediments are perhaps more readily moved or resuspended, thus inundating sluggish holothurians, than in the relatively more stable Oculina Zone of Harrington Sound or the rock ledge around Five Star Island with their esta- 
Table 3. Isostichopus badionotus. Abundance and size of individuals from Oculina and Shallow Sandy Zones on the isolated ridge in Harrington Sound

\begin{tabular}{|c|c|c|c|c|c|c|}
\hline \multirow[t]{2}{*}{ Zones } & \multicolumn{2}{|c|}{ Holothurian numbers } & \multirow{2}{*}{$\begin{array}{l}\text { Length }(\mathrm{cm}) \text { of } \\
100 \text { holothurians }\end{array}$} & \multirow{2}{*}{$\begin{array}{l}\text { Biomass }^{*}(\mathrm{~g}) \text { of } \\
20 \text { holothurians }\end{array}$} & \multirow{2}{*}{$\begin{array}{l}\text { Approximation of } \\
\text { total holothurian } \\
\text { biomass }\left(\mathrm{g} \mathrm{m}^{-2}\right)\end{array}$} & \multirow{2}{*}{$\begin{array}{l}\text { Approximation } \cdot \\
\text { of the TOM of the } \\
\text { holothurians }\left(\mathrm{g} \mathrm{m}^{-2}\right)\end{array}$} \\
\hline & $\begin{array}{ll}40 \mathrm{~m}^{-2} \\
\overline{\mathrm{x}} & \mathrm{SD}\end{array}$ & $100 \mathrm{~m}^{-2}$ & & & & \\
\hline Oculina & $9.2 \pm 2.6$ & 23 & $20.9 \pm 4.1$ & $288.6 \pm 59.1$ & 66.4 & 2.14 \\
\hline Shallow Sandy & $15.8 \pm 2.7$ & 39 & $21.3 \pm 3.6$ & $293.4 \pm 56.2$ & 114.4 & 3.69 \\
\hline
\end{tabular}

Table 4. Grain sizes of holothurian gut contents and ambient sediments from the Oculina and Shallow Sandy Zones on the isolated ridge in Harrington Sound ( $\mathrm{n}=5$ in all cases)

\begin{tabular}{|c|c|c|c|c|c|c|}
\hline \multirow{3}{*}{$\begin{array}{l}\text { Zone sediments and } \\
\text { holothurian gut contents }\end{array}$} & \multicolumn{6}{|c|}{ Mean and standard deviation of grain size $(\mu \mathrm{m})$ classes as dry weight $(\%)$} \\
\hline & \multicolumn{2}{|c|}{$>2,000 \quad 2,000-700$} & $700-515$ & $515-250$ & $250-140$ & $<140$ \\
\hline & $\overline{\mathrm{x}} \mathrm{SD}$ & $\mathrm{x} \quad \mathrm{SD}$ & $\bar{x} \quad S D$ & $\mathrm{x} \quad \mathrm{SD}$ & $\overline{\mathrm{x}} \quad \mathrm{SD}$ & $\overline{\mathrm{x}} \quad \mathrm{SD}$ \\
\hline Oculina sediments & $4.48 \pm 1.37$ & $9.80 \pm 4.46$ & $2.40 \pm 1.18$ & $7.87 \pm 0.62$ & $6.10 \pm 0.24$ & $69.35 \pm 3.80$ \\
\hline Oculina holothurians & $1.73 \pm 1.94$ & $12.22 \pm 6.77$ & $4.83 \pm 3.24$ & $12.23 \pm 4.32$ & $9.90 \pm 5.33$ & $59.09 \pm 9.80$ \\
\hline Shallow Sandy sediments & $6.69 \pm 3.00$ & $17.47 \pm 2.09$ & $9.23 \pm 0.32$ & $33.57 \pm 2.54$ & $24.88 \pm 3.23$ & $8.16 \pm 0.15$ \\
\hline Shallow Sandy holothurians & $6.45 \pm 3.94$ & $18.75 \pm 7.24$ & $11.63 \pm 7.38$ & $30.61 \pm 3.01$ & $23.50 \pm 6.06$ & $9.06 \pm 1.66$ \\
\hline
\end{tabular}

Table 5. Holothurian feces, total organic material and total phosphorus of ambient sediments from two Zones of the isolated ridge in Harrington Sound

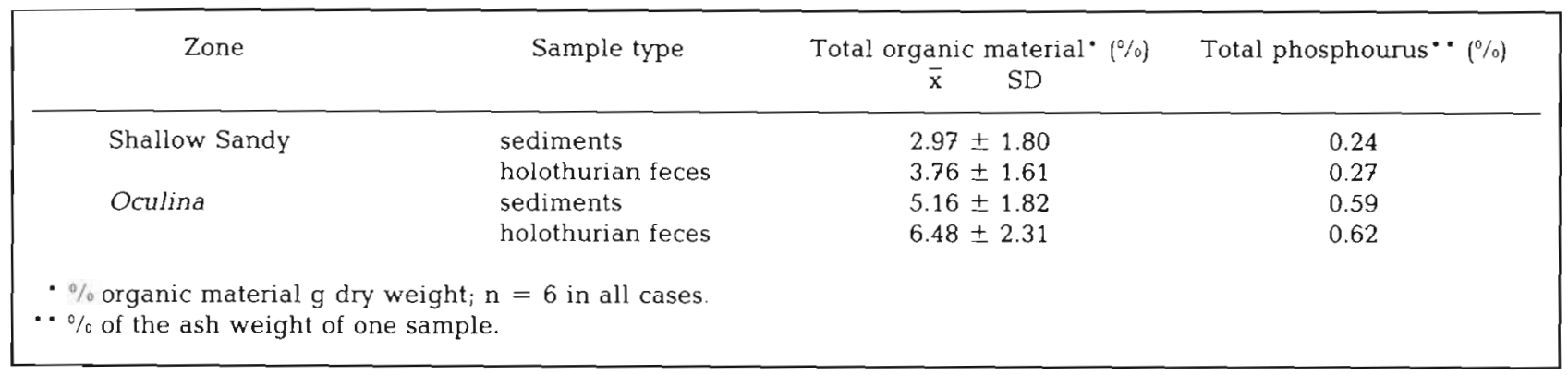

blished, dense epibenthic communities. The large $I$. badionotus may find locomotion more difficult on soft featureless muddy substrates. Around Bermuda, large I. badionotus are relatively unselective of the sediments they occupy, provided the sediments are sheltered and rendered more stable by the presence of an epibenthic community.

Within Harrington Sound, sediment porosity or total organic material cannot be correlated with holothurian abundance. Indeed, the preferred substrate of the Shallow Sandy Zone has the lowest amount of organic material in its surface sediments (Table 2). Within each zone surface sediments have the greater amount of total organic material and thus potential nutrients for these sediment-surface feeders. I. badionotus (approximate mean dry weight $19.0 \mathrm{~g}$ ) from fine Oculina Zone sediments selects weakly against the coarsest and finest fractions of ambient sediments and is not selective when occupying the coarser Shallow Sandy Zone Sediments (Table 4). By contrast, Stichopus tremulus (Gunnerus) (mean dry weight $2.17 \mathrm{~g}$ ), living on muddy substrates, selects strongly for coarser material from ambient sediments (Hauksson, 1979).

Coprophagy is well known among deposit-feeders, including holothurians (Bakus, 1973; Hauksson, 1979). Although not often observed, Isostichopus badionotus may profitably exploit its own feces because the casts have greater amounts of potential nutrients than ambient sediments (Table 5). Stichopus tremulus selectively feeds on 'faecal pellets' and 'sediment aggregates' rich in organic material, but Hauksson (1979) did not specify whether the 'pellets' were those 
Table 6 . Feeding selectivity of stichopodid holothurians

\begin{tabular}{|c|c|c|c|}
\hline Species & Reference & Locality and habitat & Remarks \\
\hline $\begin{array}{l}\text { Astichopus multifidus } \\
\text { (Sluiter) }\end{array}$ & Glynn (1965) & $\begin{array}{l}\text { Western Puerto Rico; bare } \\
\text { sandy and sea-grass } \\
\text { substrates }\end{array}$ & $\begin{array}{l}\text { Individuals found on a wide variety of } \\
\text { sediments although feeding was considered } \\
\text { more efficient on fine sediment }\end{array}$ \\
\hline $\begin{array}{l}\text { Parastichopus } \\
\text { parvimensis (H. L. Clark) }\end{array}$ & Yingst (1976) & $\begin{array}{l}\text { Southern California (USA); } \\
\text { sediment-covered rocky and } \\
\text { level substrates }\end{array}$ & $\begin{array}{l}\text { Laboratory experiments; individuals } \\
\text { utilized decomposed animal matter and } \\
\text { micro-organisms associated with plant } \\
\text { detritus but the detritus itself was not } \\
\text { utilized until decomposed; avoided } \\
\text { ingesting sediments containing blue green } \\
\text { algae }\end{array}$ \\
\hline \multirow[t]{2}{*}{$\begin{array}{l}\text { Stichopus chloronotus } \\
\text { Brandt }\end{array}$} & $\begin{array}{l}\text { Yamanouti (1939), } \\
\text { Yamonouchi (1956) }\end{array}$ & $\begin{array}{l}\text { Palao (Western Caroline } \\
\text { Islands); rubble and sand } \\
\text { reef flats }\end{array}$ & $\begin{array}{l}\text { Select finer particles from sediments, fast for } \\
\text { about } 8 \text { h before dawn }\end{array}$ \\
\hline & $\begin{array}{l}\text { Townsley and } \\
\text { Townsley (1973) }\end{array}$ & $\begin{array}{l}\text { Fanning Island (Line Islands } \\
\text { of Central South Pacific); } \\
\text { seaward reef flats and } \\
\text { lagoon passes, flats and } \\
\text { patch reefs }\end{array}$ & $\begin{array}{l}\text { Associated with finer sediments from which } \\
\text { they reject coarsest particles }(>1 \mathrm{~mm} \varnothing) \text { in } \\
\text { favor of particles around } 0.25 \mathrm{~mm} \varnothing ; \\
\text { dissolution of calcareous sediments occurs; } \\
\text { small individuals browse fine material of } \\
\text { surface of brown algae (Turbinaria sp.) }\end{array}$ \\
\hline \multirow[t]{2}{*}{$\begin{array}{l}\text { Stichopus japonicus } \\
\text { Selenka }\end{array}$} & Tanaka (1958) & $\begin{array}{l}\text { Usu Bay, Hokkaido (Japan); } \\
\text { no habitat data }\end{array}$ & $\begin{array}{l}\text { Selective ingestion of sediments proposed as } \\
\text { sediment in gut contains } 4 \times \text { total nitrogen } \\
\text { in ambient sediments; feeding periods last } \\
1.5-5 \mathrm{~h} \text {; capable of seasonal fasting } \\
\text { (Mitsukuri, 1903) }\end{array}$ \\
\hline & $\begin{array}{l}\text { Choe (1963) (cited } \\
\text { from Bakus, 1973) }\end{array}$ & $\begin{array}{l}\text { Pusan (South Korea); no } \\
\text { habitat data avalable }\end{array}$ & $\begin{array}{l}\text { Juveniles ingest 'microalgae and detritus', } \\
\text { adults are 'nonselective deposit feeders' }\end{array}$ \\
\hline $\begin{array}{l}\text { Stichopus moebii } \\
\text { Semper } \\
\text { [= Isostichopus } \\
\text { badionotus (Selenka)] }\end{array}$ & Crozier (1918) & $\begin{array}{l}\text { Bermuda; sheltered inshore } \\
\text { sandy areas }\end{array}$ & $\begin{array}{l}\text { No suggestion of selective feeding; gut } \\
\text { filled twice a day but feeding discontinuous }\end{array}$ \\
\hline \multirow[t]{2}{*}{$\begin{array}{l}\text { Stichopus tremulus } \\
\text { (Gunnerus) }\end{array}$} & $\begin{array}{l}\text { Jespersen and } \\
\text { Lutzen (1971) }\end{array}$ & $\begin{array}{l}\text { Oslofjord (Norway); muddy } \\
\text { and boulder strewn } \\
\text { substrates at } 60-200 \mathrm{~m}\end{array}$ & $\begin{array}{l}\text { Continuous, unselective feeder; may } \\
\text { aggregate near 'favorable food conditions', } \\
\text { i. e. sediments enriched by dead Fucus } \\
\text { fronds }\end{array}$ \\
\hline & Hauksson (1979) & $\begin{array}{l}\text { Raunefjord (Norway); } \\
\text { muddy substrates at } 250 \mathrm{~m}\end{array}$ & $\begin{array}{l}\text { Selectively ingests coarser material ( } 200-300 \\
\mu \mathrm{m} \text { ) from ambient sediments and } \\
\text { qualitatively selects 'faecal pellets and other } \\
\text { sediment particles, which are richer in } \\
\text { organic material' during Iaboratory and } \\
\text { in situ experiments in shallow water; results } \\
\text { differ from those of Jespersen \& Lutzen } \\
(1971)\end{array}$ \\
\hline \multirow[t]{2}{*}{$\begin{array}{l}\text { Strichopus variegatus } \\
\text { Semper }\end{array}$} & $\begin{array}{l}\text { Yamanouti (1939) } \\
\text { Yamanouchi (1956) }\end{array}$ & $\begin{array}{l}\text { Palao (Western Caroline } \\
\text { Islands); rubble and sand } \\
\text { reef flats }\end{array}$ & $\begin{array}{l}\text { Ingests less coarse sands than co-existing } \\
\text { Holothuria (Halodeima) atra Jaeger, finer } \\
\text { material when small, and coarser material } \\
\text { when larger; usually fasts for } 8 \text { h before } \\
\text { dawn }\end{array}$ \\
\hline & Roberts (1979) & $\begin{array}{l}\text { Jakarta Bay (Indonesia); } \\
\text { seaward half of wide reef } \\
\text { flats on sand or coral rubble }\end{array}$ & $\begin{array}{l}\text { Selective of sediment grain size compared to } \\
\text { the } 3 \text { other species that share its habitat; } \\
\text { selectivity related to differing tentacular } \\
\text { surface texture for each species }\end{array}$ \\
\hline $\begin{array}{l}\text { Thelenota anax H. L. } \\
\text { Clark }\end{array}$ & Lamberson (1978) & $\begin{array}{l}\text { Enewetak Atoll (Marshall } \\
\text { Islands); lagoonal flats, } \\
\text { patch reefs and channels }\end{array}$ & $\begin{array}{l}\text { A large-sized species which ingests } \\
\text { coarse sediments, shell and Halimeda sp. } \\
\text { fragments, algal fronds and small } \\
\text { molluscs }\end{array}$ \\
\hline
\end{tabular}


of $S$. tremulus. If $I$. badionotus does exploit its own feces, then areas of turbulent water conditions, where fecal casts are likely to be dispersed would not have this advantageous food resource.

We confirm Crozier's (1918) finding that local populations if Isostichopus badionotus are usually composed of individuals of similar body size. Small $I$. badionotus were not found; body size-related selectivity, well known in some holothurians and other deposit feeders (Sloan, 1979), could not be examined. Stichopodid feeding biology reviewed in Table 6 reveals how incomplete our knowledge is on these holothurians and the confusing nature of varying reports on their feeding selectivity. Sitchopodids can be generally selective of sediment grain size (e.g., Astichopus multifidus, Stichopus chloronotus, S. variegatus, Thelonota anax), qualitatively selective, according to nutrients in sediments (Parastichopus parvimensis, $S$. japonicus), or both (S. tremulus) (Table 6).

Isostichopus badionotus has no large, epibenthic Cooccurring deposit-feeding holothurian species in Bermuda to compete with. On the reef flats of Hawaii, Indonesia and Enewetak (Trefz, 1958; in Bakus, 1973; Webb et al., 1977; Roberts, 1979; Lawrence, 1980) cooccuring deposit-feeding holothurians partition resources by occupying particular areas and substrates and ingesting different grain-size classes of sediments. Perhaps in the absence of co-occuring species, $I$. badionotus has spread out into a variety of habitats and is able to exploit a range of differing food sources as do geographically isolated, and therefore 'released' from interspecific competition, predatory gastropod (Conus) species (Kohn, 1978).

Acknowledgements. We thank Dr. Walwyn Hughes, Director of the Department of Agriculture and Fisheries, for his moral support and the Bermuda Government for funding this project. Mr. Fred Dobbs and Dr. David Pawson kindly read early drafts. Members of the Bermuda Inshore Waters Investigation provided valuable field and laboratory assistance: $T$. Jickles, R. Smith, and J. Ward.

\section{LITERATURE CITED}

Bakus, G. J. (1973). The biology and ecology of tropical holothurians. In: Jones, O. A., Endean, R. (eds) Biology and geology of coral reefs, Vol. II, Biology I. Academic Press, New York, pp. 325-367

Barnes, J. A., von Bodungen, B. (eds) (1978). The Bermuda marine environment, Vol. II. Bermuda Biological Station, Spec. Publ. 17: 1-190

Berner, R. A. (1971). Principles of chemical sedimentology, McGraw-Hill, New York

Choe, S. (1963). Biology of the Japanese common sea cucumber Stichopus japonicus Selenka. Ph. D. thesis, Pusan National University, Pusan, South Korea. (cited from Bakus, 1973)

Crozier, W. J. (1918). The amount of bottom material ingested by holothurians (Stichopus). J. exp. Zool. 26: 379-389
Garrett, P., Smith, D. L., Wilson, A. O., Patriquin, D. (1971). Physiography, ecology, and sediments of two Bermuda patch reefs. J. Geol. 79: 647-668

Glynn, P. W (1965). Active movements and other aspects of the biology of Astichopus and Leptosynapta (Holothuroidea). Biol. Bull. mar. biol, Lab., Woods Hole 129: $106-127$

Hauksson, E. (1979). Feeding biology of Stichopus tremulus, a deposit-feeding holothurian. Sarsia 64: 155-160

Jespersen, A., Lutzen, J. (1971). On the ecology of the aspidochirote sea cucumber Stichopus tremulus (Gunnerus). Norweg. J. Zool. 19: 117-132

Jordan, C. F. (1973). Carbonate facies and sedimentation of patch reefs off Bermuda. Am. Ass. Petrol. Geol. Bull. 57: $42-54$

Kohn, A. J. (1978). Ecological shift and release in an isolated population: Conus miliaris at Easter Island. Ecol. Monogr. 48: $323-336$

Lamberson, J. O. (1978). Notes on the morphology, ecology and distribution of Thelenota anax H. L. Clark (Holothuroidea: Stichopodidae). Micronesica 14: 115-122

Lawrence, J. M. (1980). Numbers and biomass of the common holothuroids on the windward reef flat at Enewetak Atoll, Marshall Islands. In: Jangoux, M. (ed.) Proceeding of the second European echinoderm colloquium, Bruxelles. A. A. Balkema, Rotterdam (in press)

Mitsukuri, K. (1903). Notes on the habits and life-history of Stichopus japonicus Selenka. Annotnes Zool. jap. 5: 1-21

Morris, B., Barnes, J., Brown, F., Markham, J. (1977). The Bermuda marine environment, Vol. I. Bermuda Biological Station, Spec. Publ. 15: 1-120

Neumann, A. C. (1965). Processes of recent carbonate sedimentation in Harrington Sound, Bermuda. Bull. mar. Sci. 15: $987-1035$

Orth, R. J. (1971). The effect of turtle grass Thalassia testudinum on the benthic infauna community structure in Bermuda. In: Bricker, O. P., Vacher, H. L., Gebeline, C. D. (eds) Reports of research on organism-sediment interrelationships. Bermuda Biological Station, Spec, Publ. 9: $18-38$

Pawson, D. L. (1976). Shallow-water sea cucumbers (Echinodermata: Holothuroidea) from Carrie Bow Cay, Belize. Proc. biol. Soc. Wash. 89: 369-382

Pawson, D. L. (1978). The echinoderm fauna of Ascension Island. Smithson. Contr. Mar. Sci. 2: 1-31

Roberts, D. (1979). Deposit-feeding mechanisms and resource partitioning in tropical holothurians. J. exp. mar. Biol. Ecol. 37: 43-56

Rowe, F. W. E., Doty, J. E. (1977). The shallow-water holothurians of Guam. Micronesica 13: 217-250

Scoffin, T. P., Garrett, P. (1974). Processes in the formation and preservation of internal structure in Bermuda patch reefs. In: Cameron, A. M., Campbell, B. M., Cribb, A. B., Endean, R., Jell, J. S., Jones, O. A., Mather, P., Talbot, F. $\mathrm{H}$. (eds) Proceedings of the second international coral reef symposium. Great Barrier Reef Committee, Brisbane 2: $429-448$

Sloan, N. A. (1979). Microhabit and resource utilization in cryptic rocky intertidal echinoderms at Aldabra Atoll, Seychelles. Mar. Biol. 54: 269-279

Strickland, J. D. H., Parsons, T. R. (1972). A practical handbook of seawater analysis. Bull. Fish. Res. Bd Can. 167: $1-310$

Tanaka, Y. (1958). Feeding and digestive processes of Stichopus japonicus. Bull. Fac. Fish. Hokkaido Univ. 9: $14-28$

Townsley, S. J., Townsley, M. P. (1973). A preliminary investi- 
gation of the biology and ecology of the holothurians at Fanning Island. In: Fanning Island Expedition, July and August, 1972. Hawaii Institute of Geophysics Report HIG73-13, pp. 173-186

Trefz, S. M. (1958). The physiology and digestion of Holothuria atra Jaeger with special reference to its role in the ecology of coral reefs. Ph. D. thesis, University of Hawaii

Webb, K. L., Du Paul, W. D., D'Ella, C. F. (1977). Biomass and nutrient flux measurements on Holothuria atra populations on windward reef flats at Enewetak, Marshall Islands. In: Taylor, D. L. (ed.) Proceedings of the third international coral reef symposium. University of Miami, Miami. 1: 409-415

Yamanouchi, T. (1956). The daily activity rhythms of the holothurians in the coral reef of Palao Islands. Publs Seto mar biol. Lab 5: 347-362

Yamanouti, T. (1939). Ecological and physiological studies on the holothurians in the coral reef of Palao Islands. Palao Trop. Biol. Stud. 4: 603-636

Yingst, J. Y. (1976). The utilization of organic matter in shallow marine sediments by an epibenthic deposit-feeding holothurian. J. exp. mar. Biol. Ecol. 23: 55-69

This paper was submitted to the editor; it was accepted for publication on February 26, 1980. 